\title{
Assessing the sustainability of subsistence fisheries of small indigenous fish species: fishing mortality and exploitation of hill stream loaches in India
}

\author{
Ashwini Keskar ${ }^{1,2}$, Rajeev Raghavan ${ }^{3,4}$, Pradeep Kumkar ${ }^{5}$, Anand Padhye ${ }^{6}$ and Neelesh Dahanukar ${ }^{1,4, *}$ \\ ${ }^{1}$ Indian Institute of Science Education and Research, Pune, Maharashtra, India \\ 2 Department of Biodiversity, M.E.S. Abasaheb Garware College, Pune, India \\ ${ }^{3}$ Department of Fisheries Resource Management, Kerala University of Fisheries and Ocean Studies (KUFOS), Kochi, India \\ ${ }^{4}$ Systematics, Ecology and Conservation Laboratory, Zoo Outreach Organization, Coimbatore, India \\ ${ }^{5}$ Department of Zoology, Modern College of Arts, Science and Commerce, Ganeshkhind, Pune, India \\ ${ }^{6}$ Department of Zoology, M.E.S. Abasaheb Garware College, Pune, India
}

Received 26 May 2016 / Accepted 21 December 2016

\begin{abstract}
Small, least conspicuous fish species are targeted through subsistence fisheries in many regions of the world, but little is known about their population dynamics or exploitation levels. In the Western Ghats of India, part of a global biodiversity hotspot and an exceptional region of freshwater fish diversity and endemism, several small species of loaches are caught and sold in the local markets by marginalized communities through an unmanaged fishery, resulting in high levels of exploitation. Of particular concern is the fishery for the spiny loach, Lepidocephalichthys thermalis whose exploitation rates at various sites in the northern part of the Western Ghats region were observed to be greater than their $E_{50}$ (exploitation rate where the stock is reduced to half its virgin biomass). A comparison of various fishing sites showed that populations in the high anthropogenic impact areas (located close to urban settlements with high human population density, and impacted by various threats, i.e. introduced species, pollution) are exploited at a rate greater than $86 \%$ of their $E_{\max }$ (exploitation producing maximum yield). The first quantitative information on population dynamics and exploitation levels of small indigenous fish species in tropical rivers indicates their potential vulnerability to over fishing, and is an important starting point for further investigations into similar fisheries in other regions of Asia and Africa.
\end{abstract}

Keywords: Freshwater fish / Inland fisheries / Small-scale fisheries / Western Ghats

\section{Introduction}

Inland fisheries provide a wide range of societal benefits (Arthur et al., 2015), including providing employment and ensuring food security for millions of rural poor in the developing world (World Bank, FAO \& World Fish Center, 2012; Youn et al., 2014). Both commercial and subsistence small-scale fisheries produce most of the world's inland fish products, but it has often been difficult to differentiate the two, as both provide significant contributions to income and employment (Bartley et al., 2015), and sometimes depend on the same natural resource base (Islam and Berkes, 2016). Although most of the subsistence fisheries are directed at nutritional security of fisher households, fishers may also trade a portion of their harvest at local markets (Cooke et al., 2016), like for example in the Amazon (Almeida et al., 2003).

\footnotetext{
* Corresponding author: $\mathrm{n}$.dahanukar@iiserpune.ac.in
}

Subsistence fisheries represent one of the most obscure and complex sectors within the inland fisheries realm, further understanding of which remains a challenge, as well as an urgent necessity (Welcomme et al., 2010; Cooke et al., 2016).

In several regions of the world, especially in Africa and Asia, many small, least conspicuous indigenous fish species are harvested through subsistence fisheries (Jul-Larsen and Zwieten, 2002; Kawarazuka and Béné, 2010; Kottelat et al., 2012), both for food security (Kawarazuka and Béné, 2011) and for inclusion in specialized local cuisine (Allan et al., 2005). For example, small cyprinids contribute to almost half of the total catch from Cambodia's Tonle Sap River (Allan et al., 2005). The preference for such small fish in several African cuisines and for use in fish paste and sauces in several parts of Asia has encouraged their harvests with potential to deplete the entire assemblage (Allan et al., 2005). In spite of such large scale harvests, and knowledge that smaller-bodied freshwater fishes have an increasingly greater risk of extinction (Olden et al., 2007), small fish species have rarely been the 
focus of research on status, dynamics and trends of population and exploitation.

Hill stream fishes of superfamily Cobitioidea, generally referred to as loaches, are known by more than a thousand different species (Kottelat, 2012), but scientific knowledge on this group is mostly restricted to taxonomy and biology. Very little information exists on any demographical aspects of this group (but see Kharat and Dahanukar, 2013). Although loaches are primarily exploited for the aquarium pet trade $(\mathrm{Ng}$ and Tan, 1997; Raghavan et al., 2013) they are also harvested for food, given its nutritional and nutraceutical properties (You et al., 2009; Kiros et al., 2011; Keskar et al., 2014). In the northern region of the Western Ghats, a globally important ecoregion for freshwater fish diversity and endemism (Dahanukar et al., 2011)many native species of loaches are caught and sold by an indigenous tribal community called the Katkari - for whom fishing is one of the most profitable livelihood option and principal source of subsistence (Patnaik, 2004). This exploitation is however on-going despite suggestions by previous studies on the decline of loaches in this region (Kharat and Dahanukar, 2013; Keskar et al., 2014, 2015).

In this paper, we provide the first assessment from anywhere in the world, on the population dynamics and exploitation levels of native loaches targeted through subsistence fishery, and demonstrate the significant levels of fishing-induced mortality that these small indigenous species are subjected to.

\section{Materials and methods}

\subsection{Fish species, study sites and sample collection}

Samples of four species of hill stream loaches, Lepidocephalichthys thermalis, Indoreonectes evezardi, Paracanthocobitis mooreh and Schistura denisoni caught by the Katkari fishers from the upper reaches of the Krishna River System, Maharashtra, India and available for sale in adjoining local markets, viz. Bhor $\left(18.153^{\circ} \mathrm{N}, 73.841^{\circ} \mathrm{E}\right)$, Paud $\left(18.528^{\circ} \mathrm{N}\right.$, $\left.73.610^{\circ} \mathrm{E}\right)$ and Lonavla $\left(18.743^{\circ} \mathrm{N}, 73.409^{\circ} \mathrm{E}\right)$ all in the vicinity of Pune city (Fig. 1), which is the ninth most populated city in India (http://www.censusindia.gov.in/). Specimens were collected on a monthly basis from August 2013 to November 2015. The collection sites differed in the levels of anthropogenic stress and were divided into low anthropogenic impact area (Bhor; located farther away from city, harbours high diversity and abundance of freshwater fishes other than loaches, and the river channel is relatively less polluted by both organic and inorganic wastes) and high anthropogenic impact areas (Paud and Lonavla; located in outskirts of the city, fish populations other than loaches are impacted by over harvest and introduced species, and river channels are polluted by both organic and inorganic pollution) (see Kharat et al., 2001; Dahanukar et al., 2012). Based on the 2011 census (http://www.censusindia.gov. in/), the population at Bhor is 17,886, Lonavala is 55,652 and Paud is 3730 . However, it is essential to note that Paud serves as a market for several nearby villages and since it is located upstream of Pune city, fishes from this area are also sold in the small markets in Pune. As a result the fishing pressure is less in low anthropogenic impact area (Bhor) than high anthropogenic impact areas (Paud and Lonavla).

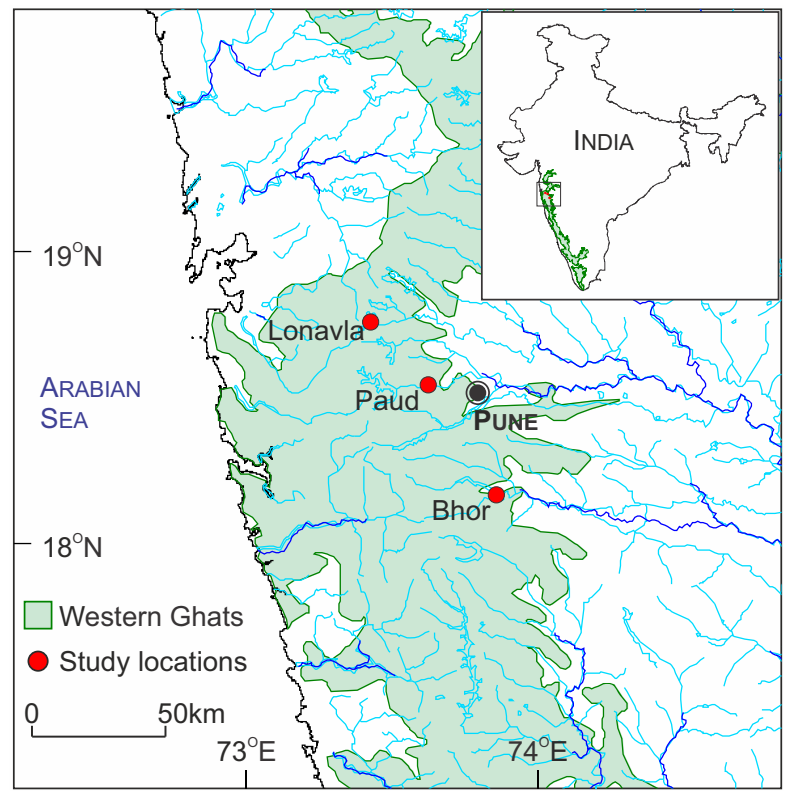

Fig. 1. Locations of the three study sites in the western part of India.

Size of the monthly sample was subject to the availability of the loaches in the markets. As the fishing technique employed by the Katkaris across the study region remained the same (use of fine-meshed drag nets), there was no bias regarding the size of the fish collected. For each fish, the standard length (SL), and the total weight (W) was measured to the nearest $0.01 \mathrm{~mm}$ and $0.01 \mathrm{~g}$ respectively.

\subsection{Data analysis}

Length frequency data was arranged such that the smallest measurement was $2.5 \mathrm{~mm}$ and the interval was $5 \mathrm{~mm}$. We checked for seasonal pattern in growth using LFDA Version 5.0 (Kirkwood et al., 2001) for Pauly's seasonal Von Bertalanfy growth formula (VBGF) using ELEFAN method (Pauly, 1984). Since there was no significant effect of seasonal pattern, further analysis was performed in FiSAT II software (FAO ICLARM Stock assessment tools II) (Gayanilo and Pauly, 1997). Asymtotic length $\left(L_{\infty}\right)$ and growth constant $K$ of VBGF were estimated using ELEFAN method (Pauly, 1984). Total mortality $Z$ was estimated from catch curve analysis and natural mortality $M$ was estimated using Pauly's $M$ equation for tropical fish: $\ln (M)=-0.0152-0.279 \ln \left(L_{\infty}\right)+0.6543 \ln (K)+$ $0.463 \ln (T)$, where $T$ is mean annual temperature, which was $26^{\circ} \mathrm{C}$. Fishing mortality $(F)$ was calculated as $F=Z-M$ and the current exploitation level $(E)$ was calculated as $E=F / Z$ (Pauly, 1984). Length converted catch curves were prepared to understand the length of first capture $\left(L_{\mathrm{c}}\right)$. Length-structured virtual population analysis (VPA) was performed based on the obtained $b$ value of length-weight relationship (allometric equation $W=a S L^{b}$; Pauly, 1984), $L_{\infty}, K, M$ and $F$. To understand whether local populations are overexploited, we calculated the theoretical $E_{50}$ (exploitation rate where the stock is reduced to half its virgin biomass) and $E_{\max }$ (exploitation producing maximum yield) using Beverton and Holt (1966) relative yield per recruit $(Y / R)$ and biomass by recruit $(B / R)$ 
Table 1. Range of length, range of weight, $b$ value for LWR and test for isometry for the four loach species from three localities.

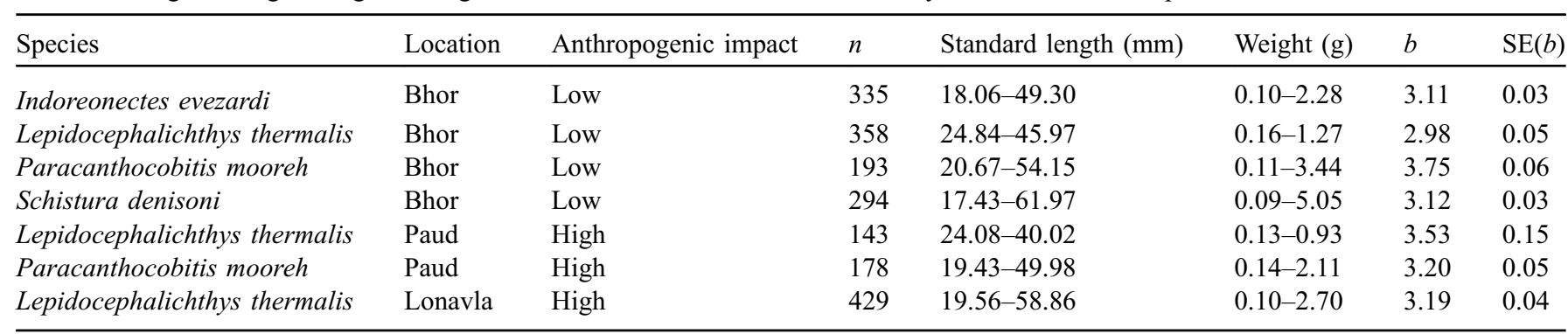

Table 2. Growth and mortality related parameters for the four loach species from three localities. Key: AS, anthropogenic impact; L, low; H, high; $L_{\infty}$, asymptotic length (mm); $K$, growth constant $\left(\mathrm{y}^{-1}\right) ; M$, mortality $\left(\mathrm{y}^{-1}\right) ; Z$, total mortality $\left(\mathrm{y}^{-1}\right) ; F$, fishing mortality $\left(\mathrm{y}^{-1}\right) ; L_{\mathrm{c}}$, length of first capture $(\mathrm{mm}) ; E$, exploitation $\left(\mathrm{y}^{-1}\right) ; E_{50}$, exploitation rate where the stock is reduced to half its virgin biomass $\left(\mathrm{y}^{-1}\right) ; E_{\mathrm{max}}$, exploitation producing maximum yield $\left(\mathrm{y}^{-1}\right)$.

\begin{tabular}{|c|c|c|c|c|c|c|c|c|c|c|c|}
\hline Species & Locality & AS & $L_{\infty}$ & $K$ & $M$ & $Z$ & $F$ & $L_{\mathrm{c}}$ & $E$ & $E_{50}$ & $E_{\max }$ \\
\hline Lepidocephalichthys thermalis & Bhor & $\mathrm{L}$ & 49.88 & 1.30 & 1.78 & 3.33 & 1.55 & 28.27 & 0.47 & 0.38 & 0.79 \\
\hline Schistura denisoni & Bhor & $\mathrm{L}$ & 65.63 & 1.60 & 1.89 & 2.80 & 0.91 & 14.30 & 0.33 & 0.30 & 0.47 \\
\hline Lepidocephalichthys thermalis & Paud & $\mathrm{H}$ & 49.88 & 0.56 & 1.03 & 3.26 & 2.24 & 24.71 & 0.69 & 0.36 & 0.76 \\
\hline Paracanthocobitis mooreh & Paud & $\mathrm{H}$ & 49.88 & 1.70 & 2.12 & 5.54 & 3.42 & 26.15 & 0.62 & 0.37 & 0.71 \\
\hline
\end{tabular}

analysis with Knife-Edge selection method by inputting the values for $L_{\infty}, L_{\mathrm{c}}, M$ and $K$. Principal component analysis (PCA) was performed to understand how the growth and mortality related parameters of the loaches from different sites differ. PCA was performed in PAST 3.09 (Hammer et al., 2001) on correlation matrix to compensate for differences in units of different parameters.

\section{Results}

\subsection{Growth and mortality related parameters}

All populations, irrespective of their anthropogenic impacts, showed a significantly (two tailed t test, $P<0.008$ ) higher $b$ value of LWR, as compared to cubic value expected from isometric growth, except for only $L$. thermalis population from Bhor (i.e. the low anthropogenic impact area, $P=0.7274$ ) (Table 1). This indicates that the weight of the fish grew with higher increments while the standard length grew with smaller increments, a result consistent with an independent study (Keskar et al., 2015) based on nonoverlapping samples. In general, populations from low anthropogenic impact area showed relatively higher asymptotic length $\left(L_{\infty}\right)$, length of first capture $\left(L_{\mathrm{c}}\right)$ and lower fishing mortality and exploitation as compared to populations from high anthropogenic impact areas (Table 2). The three populations of $L$. thermalis showed the same asymptotic length; however, population from one of the high anthropogenic impact area (i.e. Paud) had much lower growth constant $(K)$ indicating that the fish was growing at lower rate than at the other two sites. Populations of L. thermalis from high impact areas had very high fishing mortality and were captured at smaller sizes. Paracanthocobitis mooreh caught from the low impact area had a higher asymptotic length than from one of the high impact area (i.e. Paud); however the fishing mortality was less and length at first capture $\left(L_{\mathrm{c}}\right)$ was higher. Virtual Population Analysis (Fig. 2) in general showed higher fishing mortality estimates for the sites with high anthropogenic impacts. This is obvious for $P$. mooreh but less clear for $L$. thermalis, which seems to have high fishing morality rates in all the sites.

\subsection{Exploitation}

Exploitation $(E)$ of all the loach populations (Table 2) were less than the predicted $E_{\max }$ indicating that the populations were not overfished. However, there was considerable variation in the exploitation between low and high anthropogenic impact areas. All loach populations at the low impact area were exploited at lower rates with $E \leq 70 \%$ of the $E_{\max }$ values, while populations from high impact areas, were exploited at a rate $\geq 86 \%$ of their respective $E_{\max }$. All three populations of $L$. thermalis were exploited at a rate $\geq E_{50}$, but populations in the low impact area was exploited at a rate of $60 \%$ of $E_{\max }$ while the populations at high impact areas, were exploited at a rate of 91 and $93 \%$ of their respective $E_{\max }$. Exploitation of $P$. mooreh in the low impact area was $\leq E_{50}$ and was around $31 \%$ of $E_{\max }$, while much higher in the population at one of the high impact areas (Paud) which was almost twice than its expected $E_{50}$ and $87 \%$ of the $E_{\max }$. 

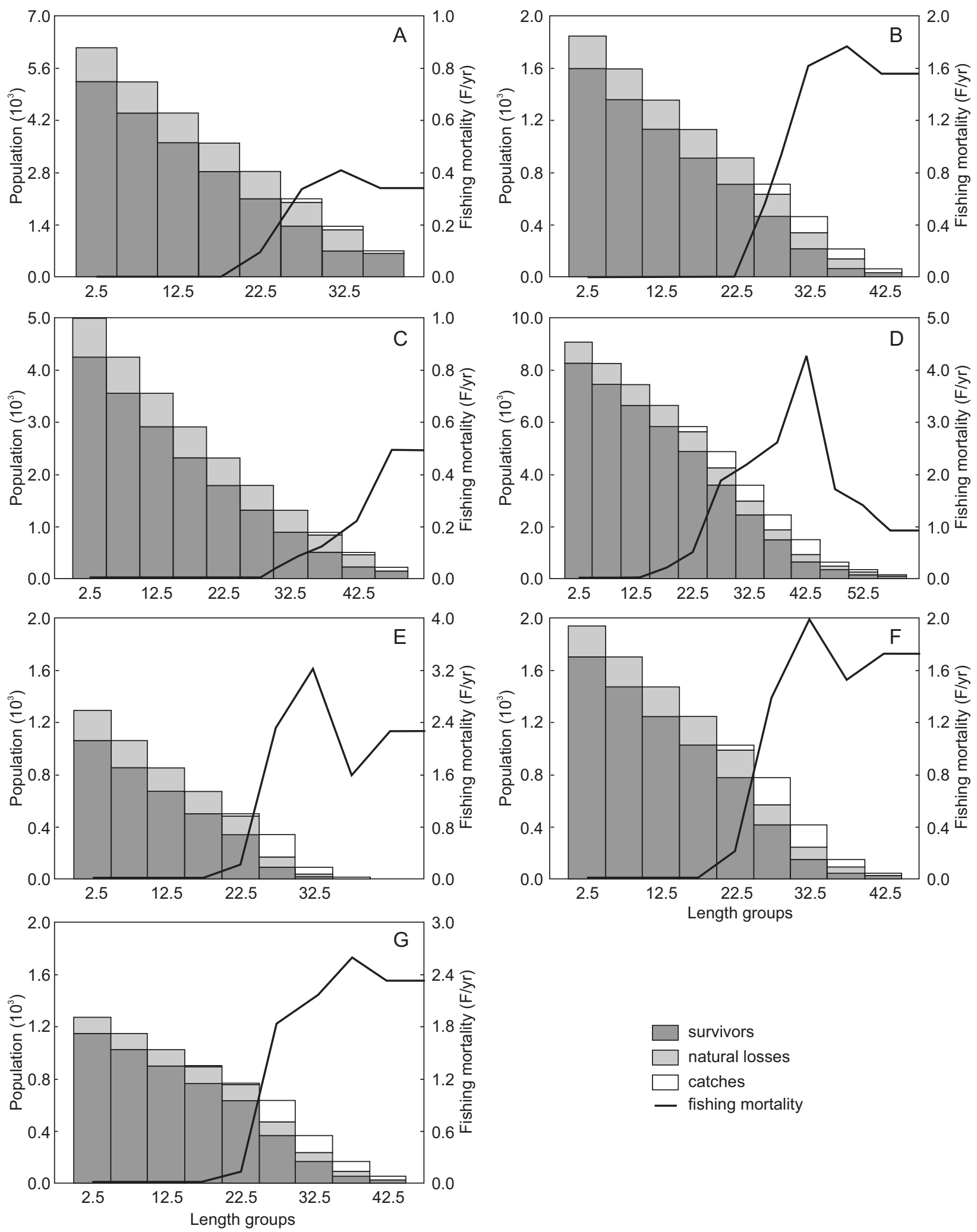

Fig. 2. Virtual population analysis of the four loach species from low anthropogenic impact (A-D) and high anthropogenic impact (E-G) localities. (A) Indoreonectes evezardi from Bhor, (B) Lepidocephalichthys thermalis from Bhor, (C) Paracanthocobitis mooreh from Bhor, (D) Schistura denisoni from Bhor, (E) L. thermalis from Paud, (F) P. mooreh from Paud and (G) L. thermalis from Lonavla. 


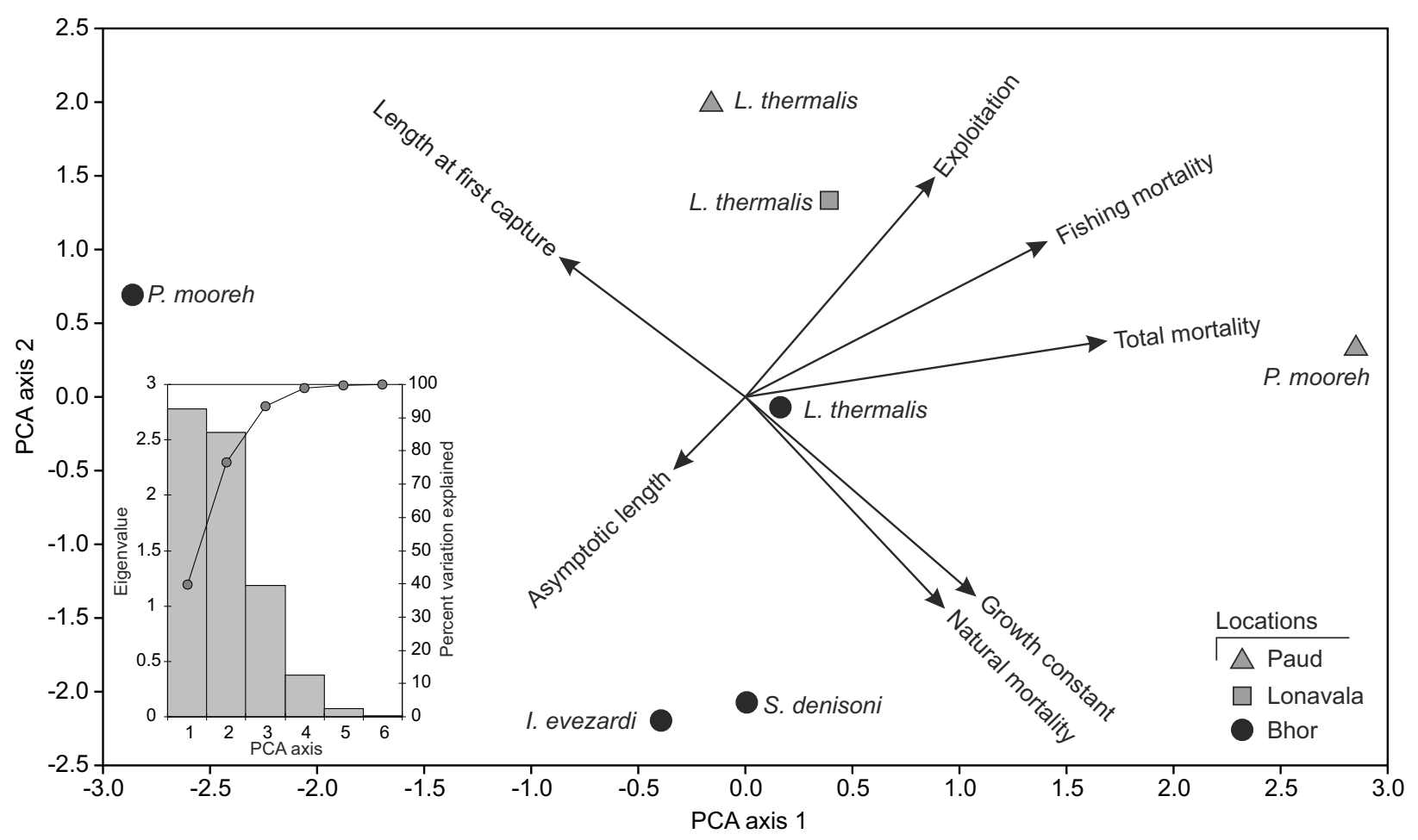

Fig. 3. Principle component analysis (PCA) of growth, mortality and exploitation related parameters for the four loach species from the low (Bhor) and high anthropogenic impact areas (Paud and Lonavla). Scree plot of percent variation explained by each PCA axis is shown in the inset.

\subsection{Multivariate analysis of growth and mortality}

When performing PCA on growth and mortality related parameters as well as exploitation parameter computed by the VPA on loach populations from the three locations (Fig. 3), we extract six axes. First two axes explained $39.7 \%$ and $36.7 \%$ of the total variation respectively (Fig. 3 inset). There was a negative relationship between asymptotic length and exploitation and between length at first capture and exploitation with respect to the first PCA axis, indicating that exploited populations reached lower asymptotic lengths and were captured mainly at smaller size. Paracanthocobitis mooreh from high anthropogenic impact area, i.e. Paud, was placed on the positive side of the first PCA axis that had positive factor loading for fishing mortality and exploitation, while the same species from low impact area, i.e. Bhor, was on the negative side of the first PCA axis. This placement of P. mooreh populations on the first PCA axis clearly depicts that the Paud population of this species is overexploited. The second PCA axis had a positive factor loading for exploitation. Populations of $L$. thermalis from both the high impact areas, Paud and Lonavala, showed positive loading on the second axis indicating that these populations were exploited relatively more than the population from low impact area, Bhor. Although, we do not have populations of $I$. evezardi and $S$. denisoni from high impact areas for comparisons, the placement of these species on the origin or negative side of the first PCA axis and negative side of the second PCA axis indicates that these species are relatively less exploited than other loach species from high impact areas.

\section{Discussion}

Conservation of exploited populations presents considerable biological and social challenges (Mace and Reynolds, 2001), especially in poorly known and documented tropical freshwater fisheries. Only very few studies have focused on the population dynamics of tropical freshwater fishes exploited through small-scale fisheries (Raghavan et al., 2011; Prasad et al., 2012) and none have looked at small fish species, despite its importance for global food security (Kawarazuka and Béné, 2011) and vulnerability to overfishing (Allan et al., 2005).

Although six species of loaches, I. evezardi, L. thermalis, Nemachilichthys ruppelli, Nemacheilus anguilla, P. mooreh and $S$. denisoni are known to occur in the study area (Kharat et al., 2003; Dahanukar et al., 2012; Keskar et al., 2014), we could not record good populations of $N$. ruppelli and $N$. anguilla from any of the sites during the present study. While, these two species were present as stray catches in the low anthropogenic impact area, they were completely absent in the markets in the high anthropogenic impact areas. Further, we could also not record good catches of $I$. evezardi, P. mooreh and $S$. denisoni from the high anthropogenic impact areas, from where these species were previously reported to occur in moderate numbers (Kharat et al., 2001; Dahanukar et al., 2012). Although several anthropogenic stressors have been identified as potential threats to fish populations in the study area (Kharat et al., 2003; Dahanukar et al., 2011, 2012; Keskar et al., 2014, 2015), there has not been any quantitative evidence as yet to understand species-specific impacts. However, in this study, we provide the first evidence that unmanaged 
exploitation can have population-level impacts on small loach species.

Our results suggest that small fish species are vulnerable to overexploitation in subsistence fisheries, unless management interventions are implemented. Loach populations in the high anthropogenic impact areas were exploited at a much higher rate (closer to their $E_{\max }$ values) than those in the low anthropogenic impact area, consistent with the theory that species living within easy reach of human settlements are easy targets for exploitation (Mace and Reynolds, 2001).

A higher fishing pressure exists on $L$. thermalis, a species that is comparatively smaller in size than its congeners occurring in this region such as $N$. ruppelli, $N$. anguilla, $P$. mooreh and $S$. denisoni. The larger sized loach species were common in the local fish markets, until two decades ago (N. Dahanukar, Pers. Observ.) after which increasing anthropogenic impacts including overfishing could have led to their local extirpation. Because loaches are sold in the local markets based on their weight, higher numbers of L. thermalis need to be exploited compared to larger loach species, subjecting the former to a higher fishing pressure as evident from the higher exploitation rates of the species in high anthropogenic impact areas.

Because we could not record good populations of I. evezardi and $S$. denisoni from high anthropogenic impact areas there is no reference point to compare the growth and mortality related parameters for these species. However, the data we have generated can be used as a baseline for future studies on other populations of these species.

\section{Conclusion}

While it is known that the inland fishery resources are intensively exploited in Asia (Welcomme et al., 2010) and many fisheries are also overexploited (Smith et al., 2005), there is little quantitative information on their impacts to the populations of small indigenous fish species and the livelihood of local communities that specialize in capturing these fish. Since small fish are primary source of protein and micronutrients to millions of people in the developing world (Hall et al., 2013), as well as an important income earner for marginalized communities, overexploitation and concomitant scarcity of these fish species will have far-reaching implications not only for fisheries, but also for global food security and livelihoods. Our study provides the first evidence on the vulnerability of small indigenous fish species to unmanaged exploitation, and is an important starting point for further studies on the long term sustainability of similar fisheries that exists in many regions of South and South East Asia.

Among several anthropogenic stressors to loach populations in the study area, which include fishing pressure, pollution of water bodies and habitat modifications, we only provide evidence for fishing pressure as a plausible threat. Therefore, it would be important to conduct a survey to determine whether environmental factors, such as habitat loss and pollution, can contribute to weaker renewal rates (due to lower fertility as example), thereby affecting loach population. Further studies that systematically address the contribution of different threats alone and in combination will be essential to design and implement conservation strategies for loaches.
Acknowledgements. This work was supported by the Department of Science and Technology (DST), India, INSPIRE Research Grant [IFA12-LSBM-21] to Neelesh Dahanukar. Ashwini Keskar and Neelesh Dahanukar thanks the Director, Indian Institute of Science Education and Research, Pune; Ashwini Keskar and Anand Padhye are grateful to the Principal and the Head of the Departments of Biodiversity and Zoology, MES Abasaheb Garware College, Pune, for providing infrastructural facilities. We thank two anonymous reviewers for valuable comments on earlier draft of the manuscript.

\section{References}

Allan JD, Abell R, Hogan Z, et al. 2005. Overfishing of inland waters. Bioscience 55: 1041-1051.

Almeida O, Lorenzen K, McGrath DG. 2003. Commercial fishing in the Brazilian Amazon: regional differentiation on fleet characteristics and economic efficiency. Fish Manag Ecol 10: 109-115.

Arthur R, Friend R, Béné C. Social benefits from inland fisheries. In: Craig JF, ed. Freshwater Fisheries Ecology. Chichester, UK: John Wiley \& Sons, Ltd, 2015, pp. 500-512.

Bartley DM, de Graaf G, Valbo-Jørgensen J. Commercial inland capture fisheries. In: Craig JF, ed. Freshwater Fisheries Ecology. Chichester, UK: John Wiley \& Sons, Ltd, 2015, pp. 438-448.

Beverton RJH, Holt SJ. 1966. Manual of methods for fish stock assessment. Part II. Tables of yield functions. FAO Fish. Tech. Pap. No. 38 Rev. 1, p. 67.

Cooke SJ, Nguyen VM, Dettmers JM, et al. Sustainable inland fisheries perspectives from the recreational, commercial and subsistence sectors from around the globe. In: Closs M, Krkosek M, Olden JD, eds. Conservation of Freshwater Fishes. Cambridge University Press, 2016, pp. 467-505.

Dahanukar N, Raghavan R, Ali A, Abraham R, Shaji CP. The status and distribution of freshwater fishes of the Western Ghats. In: Molur S, Smith KG, Daniel BA, Darwall WRT, eds. The status and distribution of freshwater biodiversity in the Western Ghats, India. Cambridge, UK/Gland, Switzerland: IUCN and Coimbatore, India: Zoo Outreach Organisation, 2011, pp. 21-48.

Dahanukar N, Paingankar MS, Raut RN, Kharat SS. 2012. Fish fauna of Indrayani River, northern Western Ghats, India. J Threat Taxa 4: 2310-2317.

Gayanilo FC, Pauly D, eds. 1997. FAO-ICLARM Stock Assessment Tools (FiSAT). Reference Manual. FAO Computerized Information Series (Fisheries) No. 8. FAO, Rome, p. 262.

Hall SJ, Hilborn R, Andrew NL, Allison EH. 2013. Innovations in capture fisheries are an imperative for nutrition security in the developing world. Proc Natl Acad Sci U S A 110 (21): 8393-8398.

Hammer Ø, Harper DAT, Paul DR. 2001. Past: paleontological statistics software package for education and data analysis. Palaeontol Electron 4: 1-9.

Islam D, Berkes F. 2016. Can small-scale commercial and subsistence fisheries coexist? Lessons from an indigenous community in northern Manitoba, Canada. Marit Stud 15: 1.

Jul-Larsen E, Zwieten PV. 2002. African freshwater fisheries: what needs to be managed? NAGA 25: 35-40.

Kawarazuka N, Béné C. 2010. Linking small-scale fisheries and aquaculture to household nutritional security: an overview. Food Secur 2: 343-357.

Kawarazuka N, Béné C. 2011. The potential role of small fish species in improving micronutrient deficiencies in developing countries: building evidence. Public Health Nutr 14: 1927-1938. 
Keskar A, Padhye A, Dahanukar N. 2014. Fighting against all odds: the struggle for existence among hill stream loaches of northern Western Ghats. Min Newsl FFSG 2: 25-29.

Keskar A, Kumkar P, Paingankar MS, Padhye A, Dahanukar N. 2015. Length-weight and length-length relationships of seven loach species (Teleostei: Cypriniformes) from five localities in northern Western Ghats, India. J Threat Taxa 7: 8205-8220.

Kharat SS, Dahanukar N. 2013. Population dynamics of the hill stream loach Acanthocobitis mooreh (Sykes, 1839) (Cypriniformes: Nemacheilidae) from northern Western Ghats of India. $J$ Threat Taxa 5: 4562-4568.

Kharat SS, Dahanukar N, Raut R. 2001. Decline of freshwater fish of Pune urban area. J Ecol Soc 13/14: 46-51.

Kharat SS, Dahanukar N, Raut R, Mahabaleshwarkar M. 2003. Long term changes in the freshwater fish fauna in the northern Western Ghats, Pune. Curr Sci 84: 816-820.

Kirkwood GP, Aukland R, Zara SJ. 2001. Length Frequency Distribution Analysis (LFDA), Version 5.0. London, UK: MRAG Ltd.

Kiros S, Aoki JY, Park CB, Soyano K. 2011. Annual changes in testicular development and plasma sex steroids in the captive male dojo loach Misgurnus anguillicaudatus. Ichthyol Res 58: 217-224.

Kottelat M. 2012. Conspectus cobitidum: an inventory of the loaches of the world (Teleostei: Cypriniformes: Cobitoidei). Raff Bull Zool Suppl 26: 1-199.

Kottelat M, Baird IG, Kullander SO, Ng HH, Parenti LR, Rainboth WJ. The status and distribution of freshwater fishes of IndoBurma. In: Allen DJ, Smith KG, Darwall WRT, compilers. The status and distribution of freshwater biodiversity in Indo-Burma. Cambridge, UK and Gland, Switzerland: IUCN, 2012, pp. 38-65.

Mace GM, Reynolds JD. Exploitation as a conservation issue. In: Reynolds JD, Mace GM, Redford KH, Robinson JG, eds. Conservation of exploited species. Cambridge University Press, 2001, pp. 3-15.

Ng PKL, Tan HH. 1997. Freshwater fishes of Southeast Asia: potential for the aquarium fish trade and conservation issues. Aquar Sci Conserv 1: 79-90.
Patnaik R. Sequential changes in occupational structure and resource availability among the Katkari of Maharashtra. In: Grover N, Singh KN, eds. Cultural geography: form and process. New Delhi: Concept Publishing Company, 2004, pp. 268-292.

Pauly D. 1984. Fish population dynamics in tropical waters: a manual for use with programmable calculators. ICLARM Study Rev 8: 325.

Prasad G, Ali A, Harikrishnan M, Raghavan R. 2012. Population dynamics of an endemic and threatened Yellow Catfish Horabagrus brachysoma (Gunther) from Periyar River, southern Western Ghats, India. J Threat Taxa 4 (2): 2333-2342.

Olden JD, Hogan ZS, Zanden MJV. 2007. Small fish, big fish, red fish, blue fish: size-biased extinction risk of the world's freshwater and marine fishes. Glob Ecol Biogeogr 16: 694-701.

Raghavan R, Ali A, Dahanukar N, Rosser A. 2011. Is the Deccan Mahseer, Tor khudree (Sykes, 1839), (Pisces: Cyprinidae) fishery in the Western Ghats sustainable? A participatory approach to stock assessment. Fish Res 110: 29-38.

Raghavan R, Dahanukar N, Tlusty M, et al. 2013. Uncovering an obscure trade: threatened freshwater fishes and the aquarium pet markets. Biol Conserv 164: 158-169.

Smith LED, Khoa NS, Lorenzen K. 2005. Livelihood functions of inland fisheries: policy implications in developing countries. Water Policy 7 (4): 359-383.

Welcomme RL, Cowx IG, Coates D, et al. 2010. Inland capture fisheries. Phil Trans $R$ Soc Lond B: Biol Sci 365: 2881-2896.

World Bank, FAO, World Fish Center. 2012. Hidden harvest: the global contribution of capture fisheries. Report No. 66469-Glb. International Bank for Reconstruction and Development/International Development Association or The World Bank, p. 69.

You L, Zhao M, Cui C, Zhao H, Yang B. 2009. Effect of degree of hydrolysis on the antioxidant activity of loach (Misgurnus anguillicaudatus) protein hydrolysates. Innov Food Sci Emerg Technol 10: 235-240.

Youn SJ, Taylor WW, Lynch AJ. 2014. Inland capture fishery contributions to global food security and threats to their future. Global Food Secur 3: 142-148.

Cite this article as: Keskar A, Raghavan R, Kumkar P, Padhye A, Dahanukar N. 2017. Assessing the sustainability of subsistence fisheries of small indigenous fish species: fishing mortality and exploitation of hill stream loaches in India. Aquat. Living Resour. 30 : 13 